\title{
Confucian Virtue Jurisprudence
}

\author{
Linghao Wang \\ Xiamen University Law School \\ Lawrence B. Solum \\ Georgetown University Law Center, Ibs32@law.georgetown.edu
}

This paper can be downloaded free of charge from:

https://scholarship.law.georgetown.edu/facpub/1352

http://ssrn.com/abstract=2080401

\footnotetext{
Linghao Wang \& Lawrence Solum, Confucian Virtue Jurisprudence, in LAW, VIRTUE AND JUSTICE (Amaya, Amalia and Ho, Hock Lai, eds., Oxford: Hart Publishing, 2012)

This open-access article is brought to you by the Georgetown Law Library. Posted with permission of the author. Follow this and additional works at: https://scholarship.law.georgetown.edu/facpub

Part of the Jurisprudence Commons, Legal Ethics and Professional Responsibility Commons, Legal History Commons, Legal Theory Commons, and the Political Theory Commons
} 


\title{
6 \\ Confucian Virtue Furisprudence
}

\author{
LINGHAO WANG AND LAWRENCE B SOLUM
}

\section{INTRODUCTION}

WHIS ESSAY SKETCHES a position in general jurisprudence that is distinctive in two ways. First, it is rooted in the traditions of Confucian L (or Ruist,儒家) thought. Second, the view of law offered in the theory is aretaic (virtue centred). We have dubbed our theory, Confucian virtue jurisprudence, with the understanding that our version of a contemporary aretaic theory of law with roots in Confucian thought is not the only possible member of a family of theories that could accurately bear that name. ${ }^{1}$ More broadly, Confucian virtue jurisprudence is a member of a larger family of aretaic legal theories, including Neo-Aristotelian versions of virtue jurisprudence. ${ }^{2}$

The tradition of Confucian thought centres on the writings of an historical figure, Confucius (Kongzi, Master Kong, or 孔子). Our focus will be on ancient thought, with an emphasis on Confucius' Analects supplemented by the views of other thinkers in the Confucian tradition. At various points, we will be concerned with issues of translation, but our main purpose is to develop a contemporary theory of law that builds on ancient foundations.

What are the elements of a general jurisprudence? Legal theorists generally take two positions in searching for answers to this meta-theoretical question. One group believes that legal theory should investigate normative questions and that the fundamental purpose of legal theory is to support prescriptive legal scholarship. A second group claims that the primary aim is description. Some members of this second group believe that this involves analysis of the concept of 'law'; others would describe the project as the development of a theoretical account of the essential or necessary features of law or legal institutions. From a Confucian perspective, however, the fundamental question in legal theory is the aim and proper

1 The most sophisticated interpretation (or reconstruction) of the classical Confucian texts from a modern jurisprudential perspective can be found in Chang (1990: chs 2, 6 and 7). Our work is inspired and influenced by his excellent scholarship on Confucian jurisprudence.

2 See Farrelly and Solum (2007). 
function of law. ${ }^{3}$ In this short essay, we sketch some of the central elements of Confucian virtue jurisprudence. We begin with an overview of Confucian thought.

\section{AN INTRODUGTION TO CONFUCIAN SOCIAL AND ETHICAL THOUGHT}

Just as Neo-Aristotelian virtue jurisprudence is developed from Aristotelian virtue ethics, ${ }^{4}$ Confucian virtue jurisprudence draws on Confucian thought.

\section{A. The Basic Structure of Confucian Moral Theory}

In Confucius' time, China's feudal system was in its final stage of collapse, causing social chaos and disorder. The old social system was fading and the new one had not yet been established, so it 'was up to the thinkers of the first millennium BC to come up with answers, solve the puzzle and restore peace. ${ }^{5}$ Confucianism is one of the schools of thought that undertook this task.

There are three main figures in early Confucianism. The first, Confucius, lived between 551 and 479 BC. Confucius' words and deeds are recorded in the Analects, a book edited by later disciples. The second figure is the 'second sage', Mencius (372-289 BC), who is famous for his positive (or optimistic) view of human nature. His moral theory has an inward-out character; he believed that self-cultivation is sufficient to lead a moral life and thus his theory focuses on the virtues. Unlike Mencius, the third thinker, Xunzi (479-221 BC), has views that could be called outward-in; he claimed that biological needs and desires are central to human nature. Xunzi believed that external habituation and deliberative correction are the only ways to rectify man's selfish nature. There are differences among the three main thinkers in early Confucianism, but we will pass them over and attempt to interpret their texts so as to reconstruct a consistent and plausible theory.

Confucian theory provides an overall account of both conduct rules and character traits. The conduct rules are Li, normally translated as rules of propriety or ritual, which refers to ceremonial rituals, proper manners in social interactions, conventional customs and even civil law (in the modern sense). The most important character traits are Ren and $Y i$, fundamental virtues in Confucian ethical theory. Ren (translated as humanity in the broad sense) is the cardinal virtue that unifies the particular moral excellences; Ren also has a narrow sense (translated as benevolence) that identifies a particular virtue related to the affective capacity con-

\footnotetext{
3 The move beyond the necessary or essential features of law is in sympathy with a view expressed by Frederick Schauer (2010).

${ }^{4}$ Solum (2006: 75-76).

${ }^{5}$ Chang (1990: 20).
} 
cerning caring for others. The virtue of $Y i$, translated as rightness or appropriateness, is a character trait related to the motivational attitude to abide by $\mathrm{Li}$ (social norms).

On the Confucian account of the relationship between rules and virtues, rulefollowing actions should be properly motivated in order to achieve a harmonious society - a well-ordered flourishing society governed by virtuous political leaders with limited use of coercion or punishment. Ideally, both citizens and rulers possess the virtues of Ren and $K i$, enabling them to act according to $L i$ for the right reasons and with the proper emotions.

Many scholars have argued that Confucian moral theory can be seen as a Chinese version of virtue ethics. For other scholars, however, the deontological notion of $L i$ has been seen as the core ideal in Confucian moral theory: Confucian Ritualism is the theory articulated by some historians to emphasise the significant importance of $L i$ in traditional Confucian society of China. ${ }^{6}$

We will interpret Confucian thought as a particular version of virtue ethics in the sense specified by Michael Slote; a virtue ethics that (1) takes aretaic notions rather than deontological notions as primary and (2) emphasises moral evaluation of agents and their motives and character traits. ${ }^{7}$ Early Confucian ethical thought is a virtue ethics in Slote's sense. ${ }^{8}$

The aretaic character of Confucian thought is consistent with the role played by $L i$ (or social norms that provide comprehensive governance of social life). Confucian thought posits that ideal moral agents (in the conditions of traditional Chinese society) should strictly observe $L i$. In the Analects, we read, 'Do not look unless it is in accordance with $L i$; do not listen unless it is in accordance with $L i$; do not speak unless it is in accordance with $L i$; do not move unless it is in accordance with $L i{ }^{9}$

So on the one hand, we have a deontological notion $L i$, which functions as a set of external rules specifying right action. But on the other hand, we have Ren and $\mathrm{Y}_{i}$, which are virtues or character traits. Ren is more fundamental than $L i$; as Confucius once said, 'A man who is not Ren - what has he to do with Li?' ${ }^{10}$ The virtue of $Y_{i}$ is related to the proper motivational attitudes of abiding by $L i$. In another place in the Analects, Confucius stated that $L i$ is the form and $Y_{i} i$ is the essence in virtuous agents' moral lives. ${ }^{11}$ So, virtues are more fundamental than rules $^{12}$ and moral evaluation of agents' characters is primary.

See Chow (1994).

7 See Slote (1992: 89).

${ }^{8}$ Wai-Ying Wong has an excellent discussion of the distinctive features of virtue ethics and its relationship to Confucian moral theory. See Wong (2001: 286-89). A lot of important works in Chinese philosophy have been devoted to an aretaic reading of Confucian ethics. See eg Gier (2001: 280-305); Slingerland (2001: 97-125); van Norden (2007); and Yu (1998: 323-47).

${ }^{9}$ Confucius (2001: 32), with some modifications to the translation.

10 ibid 7, with some modifications to the translation.

11 ibid 41 .

${ }^{12}$ By claiming 'more fundamental', we are not arguing that $L i$ loses its independent value or that $L i$ can be deduced from virtues. 
Confucian ethics incorporates both aretaic notions and deontological notions, postulating a harmonious unity of the external rules and internal virtues. The deontic and aretaic elements are unified by the social roles of agents; those roles govern relationships between members of the community. The same agent might occupy different roles in connection with different relationships. For example, a woman might be a mother with regard to the relationship between her and her children and simultaneously a disciple with regard to the relationship between her and her teacher.

Thus, we can summarise as follows: $L i$ prescribes rules attached to roles. Ren is the cardinal virtue of humanity and the particular virtue of benevolence. $\mathrm{Ni}$ can be seen as an intermediate between the deontological notion $L i$ and aretaic notion Ren by specifying the motivational attitude appropriate to the fulfilment of responsibilities and duties attached to social roles. Thus, Confucian moral thought is a role-based virtue ethics. It is role-based because 'it is based on the roles that make an agent the person he or she is' ${ }^{\prime 3}$ it is a virtue ethics because the ultimate concern of early Confucian thinkers was the inner characters of moral agents. The diagram below roughly shows the structure of Confucian ethics:

$$
\text { Li (Social norms) Role }
$$

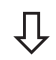

Yi (Properly motivated to fulfill the responsibilities and duties set by $L i$ )

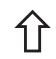

$$
\text { Ren (Fundamental virtue) }
$$

Agents who possesses all the virtues are $\mathcal{F} u n z i$ (君子), commonly translated as gentleman or superior man in English. A Junzi possesses all the virtues, and thus he or she is able to autonomously abide by the external rules specified by $L i$ in accord with his or her own dispositions. Someone who is a funzi and lives under favourable conditions could be said to live a flourishing life. We might call this view of human flourishing the harmony conception of human flourishing. The life of a funzi is harmonious because in such a life the aims or values of the individual are consistent with the social norms of the community in which the agent lives.

With the overview complete, we now provide a fuller description of the fundamental concepts in Confucian ethical and social thought; these concepts are the building blocks of the Confucian virtue jurisprudence we sketch in the next part.

13 Nuyen (2009). 


\section{B. Four Concepts: $\mathrm{Li}$, Correcting Names, $\mathrm{Yi}$, and Ren}

i. $L i$

There was no word precisely corresponding to positive law in ancient China. Nonetheless, there were traditional norms governing human conduct and coordinating social interactions; these norms formed the normative domain called Li (禮) - a crucial ideal in Confucian practical philosophy. However, since this Chinese word has undergone a long history of linguistic evolution, the meaning and scope of $L i$ has changed over time. The conventional view is that $L i$ originated from the practice of sacrifice; $L i$ was constituted by the rules specifying rituals governing sacrifices performed by individuals or groups in honour of their common ancestors. ${ }^{14}$ Later, the scope of $L i$ was extended to include etiquette and proper manners in social interaction. Our view is that the scope of $L i$ in the Confucian context refers to the whole normative system in the society, including the rituals and rites in the sacrifice ceremony, etiquette, moral rules and political institutions, and even some rules we would not call laws. ${ }^{15}$

But our conception of $L i$ is not an idea limited to a purely external standard of conduct. Confucius made this point explicit in his comparison between governing people by government regulations backed by punishments and guiding people by virtues and $L i$ :

The Master said, 'If the people be led by governmental regulations, and uniformity sought to be given them by punishments, they will try to avoid the punishment, but have no sense of shame. If they be led by virtue, and uniformity sought to be given them

by $L i$, they will have the sense of shame, and moreover will reform themselves. ${ }^{16}$

From this comparison, we know that $L i$ has an internal aspect and is necessarily connected with the emotion of shame and the virtue of $\mathrm{Yi}_{i}{ }^{17}$

Why was $L i$ necessary for social order? Confucian philosophers answered this question by developing several functional arguments. For Xunzi, the primary function of $L i$ is the coordination of social interactions and the creation of social order: we call this the social coordinative function. Xunzi claims that human beings have natural desires while the good is insufficient for the fulfilment of people's desires. If these desires are left unregulated, 'there will be chaos' and people 'will be impoverished'. ${ }^{18}$ $\mathrm{Li}$ can provide a proper common ground for social interactions and overcome the problem of chaos produced by unregulated natural desires. Moreover, by regulating resource distribution, $\mathrm{Li}$ can produce prosperity. ${ }^{19}$

${ }^{14}$ Chang (1983: 37).

15 It was common in the history of Imperial China for $L i$ to be codified and enacted by political authority.

${ }^{16}$ Confucius (1971: 146), with some modifications to the translation.

17 The relationship between the emotion of shame and $L i$ will be discussed more thoroughly in our investigation of the virtue $Y i$.

18 Xunzi (2001: 265).

19 ibid. 
In Confucian role-based virtue ethics, $L i$ provides information about social rules to which moral responsibilities are attached. These ethical roles are closely connected with five crucial ethical relationships (君子), which are (1) that between parents and children; (2) that between ruler and subject; (3) that between husband and wife; (4) that between elder and younger brother; and (5) that between friends. ${ }^{20} \mathrm{Li}$ can be described as a sort of social grammar, which 'provides each member with a defined place and status within the family, community, and polity'. ${ }^{21}$

$L i$ also has an expressive function; it enables the expression of sentiments and dispositions. There are two typical ways in which $L i$ performs this expressive function: first, the rules of $L i$ set up uniform standards in circumstances and regulate the agents' feeling of certain emotions; and, second, the rules of Li provide agents a proper way to successfully express their emotions. ${ }^{22}$

Since Confucian theory is a role-based virtue ethics, 'a moral agent must aim not only at the cultivation of right feelings, but also at the right expression of these feelings in proper context'. ${ }^{23}$ For Confucius, $L i$ has a fundamental role in the practice of some virtues. ${ }^{24} \mathrm{Li}$ sets standards for the proper manner and right feeling of emotions in particular contexts of social interactions. As Confucius put it, without agents' observance of $\mathrm{Li}$, some virtues will become vices.

Finally, $L i$ has a constitutive role for human beings as social creatures. This theme can be seen as a further development of the coordinative function and the expressive function. $L i$ incorporates rules of propriety, rituals, customs and law. From the social perspective, $L i$ 's coordinative function establishes the foundation of social life. From the personal perspective, the expressive function of $\mathrm{Li}$ provides agents with a means and standard for the expression of their interior dispositions. Thus, we say that $L i$ has a constitutive role. $L i$ is like 'the cement of the entire normative sociopolitical order', ${ }^{25}$ which binds 'human beings and the spirits together in networks of interacting roles within the family, within the human society, and with the numinous realms beyond. ${ }^{26}$

\section{ii. Correcting Names}

The next idea that we examine is the doctrine of correcting names and the associated concept of name (名). Confucian philosophers developed an account of the use of names (ie characters in writing and by words and phrases in speech) in moral language and recommended a doctrine of correcting names (正名) as the principle

20 Mengzi (2001: 127).

21 Ames and Rosemont (1988: 51).

22 See Lifi: Tan Gong (《礼记·檀弓》). Also see Chang (1990: 12).

${ }^{23}$ Cua (1971: 134).

${ }^{24} \mathrm{eg}$ he claims that '[r] espectfulness, without $\mathrm{Li}$, becomes laborious bustle; prudence, without $\mathrm{Li}$, becomes timidity; courage, without $\mathrm{Li}$, becomes insubordination; straightforwardness, without $\mathrm{Li}$, becomes rudeness.' Confucius (1971: 162), with some modifications to the translation.

${ }_{25}$ Schwartz (1985: 67).

26 ibid. 
for the proper use of moral language. In this part of the essay, we interpret names as thick ethical concepts; this account of names is then used to illuminate the nature of the practice of correcting names.

The phrase correcting names appears only once in the Analects. ${ }^{27}$ For Confucius, the correction of names is crucial to the establishment of a stable social order. Confucius offered a chain of arguments, within which the notion of correcting names operates as the most fundamental premise.

If names be not correct, language is not in accordance with actuality. If language be not in accordance with actuality, affairs cannot be carried on to success. When affairs cannot be carried on to success, $L i$ and music will not flourish. When $L i$ and music do not flourish, punishments will miss the mark. When punishments miss the mark, the people do not know how to move hand or foot. Therefore a superior man considers it necessary that the names he uses may be spoken appropriately and also that what he speaks may be carried out appropriately. ${ }^{28}$

In other words, this passage suggests that Confucius viewed the proper use of names as a precondition of social practice that functions well.

Ethical names have two functions: one is descriptive and the other is prescriptive. On the one hand, names have a descriptive function that enables us to make reference to different things or describe different properties of things in the world. In this regard, correcting names 'constructs a model of the proper function of language on the basis of the claim that the role of "names" (generally, substance words) is to distinguish differences in "realities". ${ }^{29}$ With the use of names, we can understand one another's beliefs about the world and communicate with each other. For example, the names of lord, minister, father and son refer to different people who possess these social roles.

On the other hand, names have a prescriptive function that is deeply connected with the traditional norms of $\mathrm{Li}$. For example, the meaning of lord should be understood in its connection to the virtues, duties and proper ways of behaviour of a morally ideal lord. In ancient China, someone who properly understood the name of lord would have applied lord to express their normative expectations of the men who were actually in charge of political affairs.

Understood literally, the process of correcting names seems to be the reestablishment of the proper correspondence between names and the actual state of ethical practice. However, this understanding does not specify the object of correction, which could be either ethical practice or linguistic practice. From the descriptive perspective, the actuality of ethical practice is prior to the description, thus the object of correction (in the practice of correcting names) is current usage of the relevant names. ${ }^{30}$ But from the prescriptive perspective, names imply the standards of actions, thus the objects of correction should be the actual states of affairs or actions that are connected with the prescriptive content of the names.

${ }^{27}$ Confucius (1971: 263-64).

28 ibid, with some modifications to the translation.

${ }^{29}$ Eno (1990: 146).

${ }^{30}$ Fung (1952: 60). 


\section{Confucian Virtue Jurisprudence}

So what is the nature of the Confucian idea of 'names'? Descriptive, prescriptive, or both? Bernard Williams' account of what he called 'thick ethical concepts' gives us a clearer picture of the descriptive and prescriptive features of names as well as the relationship between these two features.

The notion of thick ethical terms was introduced by Williams in his influential work Ethics and the Limits of Philosophy, where he famously distinguished thick ethical concepts from thin ones. Thick ethical concepts include words like brutality or courage, which carry more factual or descriptive content than thin ethical concepts like right or wrong. Thin ethical concepts do not contain substantive information about states of affairs: from an assertion that a situation is good or an action is right, we can infer very little about the nature of the situation or action. But thick ethical concepts are different. For example, if an action is described as courageous, then we know that the agent faced the danger in an appropriate way.

Because thick ethical concepts are world-guided, they can facilitate moral convergence among the members of a particular community and serve as the basis for social coordination. By way of contrast, thin concepts (like right or good) lack this close connection to facts about the world, and for this reason, thin concepts cannot facilitate agreement by providing a basis for agreement in judgements about particular cases.

We can characterise thick and thin ethical concepts as follows. Thin ethical concepts are concepts that only have general and abstract evaluative or prescriptive content. Thick ethical concepts are ethical concepts that have both descriptive content and prescriptive content. For Williams, thick ethical concepts may have another crucial feature; they imply 'a union of fact and value': 'The way these notions are applied is determined by what the world is like (for instance, by how someone has behaved), and yet, at the same time, their application usually involves a certain valuation of the situation, of persons or actions. ${ }^{31}$ Thus, thick ethical terms are both 'world-guided' and 'action-guiding' at the same time.

Thick ethical concepts are world-guided because the application of a thick ethical term is guided by facts about the world. These concepts are also action-guiding, in the sense that thick ethical concepts provide standards that give reasons for action and can be used to evaluate actions. ${ }^{32}$ For example, if someone describes an action as 'cruel', she has a reason not to do that action: the cruelty of the action provides her with a reason to refrain from engaging in the action.

The third feature, and also the most important one, is what we call the amalgam nature of thick concepts. A thick concept represents an indissolubly united amalgam of description and evaluation. ${ }^{33}$ This amalgam nature has two dimensions, which we theorise as nondetachability and underdeterminacy.

On the one hand, thick concepts convey an evaluative attitude directed at a specific feature of a person, action or circumstance. Or, we might say that the

\footnotetext{
31 Williams (2006: 129).

32 ibid 140.

33 See Payne (2005: 96).
} 
evaluative attitude is expressed in the light of the description. ${ }^{34}$ When we say that an action is cruel, we are not making an all-things-considered assessment of that action but an assessment of a specific descriptive property of that action. This feature of thick concepts could be conceptualised as the Nondetachability Thesis. ${ }^{35}$ The evaluative content of a thick concept is always the evaluation of one or more descriptive elements of that concept that cannot be fully detached from the concept's descriptive content.

On the other hand, users of thick concepts specify descriptive content from an evaluative point of view that is constructed by shared human needs, interests and concerns. ${ }^{36}$ For example, the evaluative point in the application of rudeness might be constructed by a particular concern of politeness or good manners in social interaction; so the thick concept rudeness might cover a wide range of actions. ${ }^{37}$ To apply thick concepts correctly, people always need to resort to the evaluative point underneath the concept. This aspect of thick concepts is described by the Underdeterminacy Thesis: ${ }^{38}$ the descriptive content of a concept alone cannot adequately determine the application of that concept. The implication of the Underdeterminacy Thesis is that a thick concept may lack a natural shape, ${ }^{39}$ a shape that is defined solely by its descriptive elements. Instead, such concepts have a normative shape or evaluative shape that is organised by their evaluative point.

William's notion of thick ethical concepts and the amalgam account of their nature help to provide a much clearer understanding of the Confucian idea of names and the related practice of correcting names. In the traditional understanding of Chinese scholars, there is some tension between the descriptive and the prescriptive view of names. Williams' notion captures the nature of Confucian names and provides us with a new perspective on the superficial tension between the descriptive function and prescriptive function.

Confucian names, qua thick ethical concepts, are indissolubly united ethical concepts combining descriptive and prescriptive elements. They can both serve the function of categories distinguishing like from unlike and have ethical implications indicating what is particularly right and morally wrong. The use of names of this sort can be improper for either one of two reasons: (1) inability to track the world or (2) inability to provide appropriate guidance for actions. If we understand the doctrine of correcting names in this way, then the objects of correction turn out to be the mistaken application of names to actions or persons. Whether to change the name to capture the genuine features of the world - as Mencius did when he rectified the name of lord - or to reveal the true moral implications of existing names as Confucius did when he emphasised the importance of fulfilment of duties connected to social roles - depends on the particular circumstances. Improper use

\footnotetext{
34 See Blackburn (1992: 289).

35 A more complete account is provided in Wang (2010).

36 See Feldman (1994: 1195, 1196).

37 See Goldie (2008: 97).

38 See Wang (2010).

${ }^{39}$ For discussions of the naturally shapeless nature of thick concepts, see Dancy (1996: 263).
} 
of a thick ethical concept can prompt either one of two responses: we can change the way we talk (apply the correct name) or we can change the way we act (act in accord with the correct name).

Since names are concepts with rich ethical meaning, they provide ethical guidance for actions. Confucian philosophers' ultimate goal in emphasising the correction of names is to give people ethical guidance through the application of names in the correct way and to the correct persons and actions. For example, the spontaneous application of the name regicide by an agent provides a reason not to kill. ${ }^{40}$ Similarly, the application of the word cruel to a type of punishment gives us a reason not to use that kind of punishment.

iii. $Y i$

$Y_{i}$ is normally translated as rightness, righteousness, appropriateness, or dutifulness. Since $\mathrm{Yi}$ functions as an intermediary between $\mathrm{Ren}$ and $\mathrm{Li}$, that is, between an aretaic notion and a deontological notion, there might be some confusion about the nature of $Y i$. In the Analects, $Y i$ refers to the quality of actions ${ }^{41}$ and thus it might be understood as a deontological term. But $Y_{i}$ sometimes refers to the attribute of persons ${ }^{42}$ and thus it might be understood as an aretaic concept.

The key to answering the question of whether $Y i$ is aretaic or deontological lies in the relationship between $\mathrm{Ki}_{i}$ and $\mathrm{Li}$. Another paragraph in the Analects sheds some light on this relationship:

The Master said, 'The funzi takes $Y i$ as essential. He performs it according to $L i$, gives it expression through modesty, and perfects it with sincerity. This is indeed a funzi. ${ }^{43}$

This remark implies that $\mathrm{Li}$ cannot be reduced to external rightness. To perform the right action in the particular circumstances, one must have the right feelings and express these feelings rightly. ${ }^{44}$ This is why Confucius asked, 'A man who is not Ren - what has he to do with $L i$ ? ${ }^{45}$ Since Ren is a fundamental virtue - with content that is too abstract to connect directly with $L i-Y i$ can be conceived as a virtue that mediates between $R e n$ and $L i$. On this account, $Y_{i}$ harmonises external rightness $(L i)$ with internal rightness $(R e n)$.

Because $Y i$ mainly deals with the social norms that constitute $L i{ }^{46}{ }^{4 i}$ can be seen as a virtue concerning the motivational attitudes of actors who observe these social norms. A person possessing $Y_{i}$ is motivated in the right way to fulfil the responsibilities and duties of $\mathrm{Li}$. Confucius did not elaborate on what exactly the appropriate motivation is, but he ruled out the motivations based on personal

${ }^{40}$ Of course, the reason might not be an exclusive or decisive one, as Williams pointed out. See Williams (2006: 140). In other words, these reasons are defensible.

${ }^{41}$ See Shun (1997: 25).

${ }^{42}$ See ibid 26.

43 Confucius (1971: 299), with some modifications to the translation.

${ }^{44}$ See Cua (1971: 134).

${ }^{45}$ Confucius (2001: 7).

${ }^{46}$ See Cua (2007: 134). 
gain. ${ }^{47}$ This distinction between $Y_{i}$ and profit is one of the central theses in the Confucian tradition of ethical and political thought. ${ }^{48}$

$Y i$ is connected with the emotions of shame (羞) and aversion (惡). Mencius famously claimed that 'the heart of shame and aversion is $\mathrm{Ki}^{\prime}{ }^{49}$ As Mencius explains, the core of shame involves a negative emotion triggered by failure to conform to $\mathrm{Li} .{ }^{50}$ In the western tradition, we can distinguish conventional shame from ethical shame. Conventional shame 'is a sort of unpleasant feeling we have when we believe those whose views matter to us look down on us (or on those with whom we identify) on the basis of a standard of appearance we share' ${ }^{51}$ Ethical shame 'is a sort of unpleasant feeling we have when we believe that we (or those with whom we identify) have significant character flaws. ${ }^{95}$

What kind of shame was the concern of early Confucianists? On the one hand, they emphasised the importance of self-cultivation, so ethical shame would be of the right kind. This view is supported by Mencius' recognition that the sense of shame is a crucial element in ethical self-cultivation. ${ }^{53}$ On the other hand, $L i$ has an independent and irreducible role in the whole theoretical structure, and conventional shame will support agents in their attempts to abide by social norms. When Confucius emphasised the crucial role of the sense of shame in the political contexts, ${ }^{54}$ his views seem to involve conventional shame as the mechanism that creates social pressure and thus maintains the social order.

We conclude that the emotions connected to $F_{i}$ include both conventional shame and ethical shame. Both forms of shame motivate agents to act according to the rules in $L i$. From another perspective, we might say that $L i$ is internalised by agents with the help of $\mathrm{Yi}$. Li provides the concrete, formal way of the expression of Ren (in the general sense) and $V_{i}$ sets the appropriate internal attitudes and emotions in the process of expression. $Y_{i}$ provides harmony between external standards and internal virtues.

\section{iv. Ren}

Now we come to the most fundamental virtue, Ren, which has both a broad and a narrow sense. ${ }^{55}$ Ren in the narrow sense is translated as benevolence, which is connected with the natural affective capacity of humans; in this context, benevolence means caring for or loving others. The broad sense of Ren is more ambiguous; it is

\footnotetext{
${ }^{47}$ The Master said, 'The Funzi understands what is $Y i$, the petty person understands what is profit.' Confucius (2001: 11).

48 See eg Mengzi (2001: 113).

49 Mengzi (2001: 143), with some modifications to the translation.

${ }^{50}$ See Shun (1997: 58). See also van Norden (2007: 262).

51 van Norden (2007: 259).

52 ibid 260.

${ }^{53}$ Mencius said, 'A sense of dishonor is indeed important for people. Those who are crafty in their contrivances and schemes have no use for dishonor. If one is not ashamed of not being as good as others, how will one ever be as good as others?' Mengzi (2001: 148), with some modifications to the translation.

${ }^{54}$ See Confucius (1971: 146).

${ }^{55}$ See Shun (1997: 23-24).
} 
translated as perfect virtue, goodness, humaneness, or humanity. Ren in the broad sense is regarded as the unity of all the virtues including Ren in the narrow sense.

The broad sense of Ren was not elaborated on in the Analects, but we can characterise Ren in the broad sense by examining more particular virtues such as filiality. The virtue of filiality (or filial loyalty and respect, 孝) is regarded as the root of the development of Ren. In the Analects, we read at the opening of the text that, 'The funzi applies himself to the roots. That being established, all practical courses naturally grow up. Filial piety and brotherly respect! - are they not the root of all benevolent actions? ${ }^{56}$

Though Ren in the broad sense is an abstract notion concerned with interpersonal relations, the cultivation of Ren occurs within the family and with the people to whom we are most closely connected. So filiality is the preliminary form of Ren. An agent who fully extends the virtue of filiality to all social relations is a Ren agent. But extension of filiality to other social relationships is context-sensitive: the kind of respect that is due to members of one's family will not be identical to the kind of respect that is due to a friend, co-worker, or official.

Another virtue involved in the development of the broad sense of Ren is courage. Confucius once remarked that, 'men possessing Ren are sure to be courageous, but those who are courageous may not always be men possessing Ren. ${ }^{57}$ Joining filiality and courage are several other virtues that are united in the broad sense of Ren: these particular virtues are reverence, respectfulness, loyalty ${ }^{58}$ tolerance, trustworthiness, quickness and generosity. ${ }^{59}$

The general notion of Ren represents the highest human achievement in ethical self-cultivation, hence the common translation as humanity. In addition, Ren involves action conforming to social norms and therefore Ren constrains action on the basis of unrestricted desires and impulses:

Yan Hui asked about Ren. The Master said, 'Restraining yourself and returning to $L i$ constitutes Ren. If for one day you managed to restrain yourself and return to $L i$, in this way you could lead the entire world back to Ren. ${ }^{90}$

Human beings have natural desires and impulses, but given the social nature of human beings the expression of these desires can and should be regulated by $\mathrm{Li}$. Ren is the virtue that endows 'these feelings, impulses, and desires with a signifi-

56 Confucius (1971: 139), with some modifications to the translation.

57 ibid 276, with some modifications to the translation.

${ }^{58}$ Fan Chi asked about Ren. The Master said, 'While at home hold yourself in a respectful attitude; when serving in an official capacity be reverent; when dealing with others be loyal. These are qualities that cannot be put aside, even when you go and live among the barbarians.' Confucius (1979: 121).

59 Zizhang asked Confucius about Ren. Confucius said, 'There are five things and whoever is capable of putting them into practice in the world is certainly Ren.' When asked for details, he went on, 'They are respectfulness, tolerance, trustworthiness, quickness, and generosity. If a man is respectful he will not be treated with insolence. If he is tolerant he will win the multitude. If he is trustworthy in word his fellow men will entrust him with responsibility. If he is quick he will achieve results. If he is generous, he will be good enough to be put in a position over his fellow men.' Confucius (1979: 144), with some modifications to the translation.

${ }^{60}$ Confucius (2001: 32), with some modifications to the translation. 
cance beyond their de facto character' ${ }^{61}$ The general notion of Ren was articulated by Cua as 'moral life at its best' and the 'thematic unity of Confucian discourse'. ${ }^{62}$ Although these characterisations of Ren are very abstract, they point to the unifying character of Ren: particular virtues are unified by and constitutive of the general virtue of Ren.

The narrow sense of Ren mainly concerns empathetic affections in the ethical life. It is illustrated in Mencius' claim that '[ $\mathrm{t}]$ he heart of compassion is benevolence. ${ }^{63}$ Confucius' thin definition of this narrow sense of Ren is loving people. ${ }^{64}$ However, in Confucius' understanding of Ren, there might be two aspects expressed in two formulas, related to Ren as the practice of loving or caring for persons. The positive formula is as follows:

Desiring to take his stand, one who is Ren helps others to take their stand; wanting to realize himself, he helps others to realize themselves. ${ }^{65}$

And the passive formula is this: 'Do not impose upon others what you yourself do not desire.' 66

These formulas emphasise the empathetic nature of Ren. The two formulas require the virtuous agent to examine the impact of her decisions from the perspective of the persons who are affected by her actions. However, since Ren is supposed to be a virtue, ${ }^{67}$ these formulas should be understood as a requirement of empathy (as a disposition of character) rather than a requirement that agents engage in a particular procedure of practical reasoning: hence, Ren differs from Kant's notion of the categorical imperative understood as a decision procedure for ethics.

On Mencius' account, each virtue is connected with an emotion. According to Mencius, the emotion connected with Ren is sympathy or compassion; his account of the connection is based on his conception of human nature. Mencius argued for his positive conception via a thought experiment, which he described as follows:

The reason why I say that humans all have hearts that are not unfeeling toward others is this. Suppose someone suddenly saw a child about to fall into a well: everyone in such a situation would have a feeling of alarm and compassion - not because one sought to get in good with the child's parents, not because one wanted fame among their neighbors and friends, and not because one would dislike the sound of the child's cries. ${ }^{68}$

Mencius' thought experiment is designed to elicit the natural moral reactions of human beings towards the accident. The baby is going to fall into the well! It happens suddenly, and for this reason, it tests the gut reactions of human beings and

${ }^{61}$ Cua (1971: 132).

62 ibid 127.

63 Mengzi (2001: 143).

${ }^{64}$ See Confucius (1979: 116-17).

${ }^{65}$ Confucius (2001: 19), with some modifications to the translation.

66 ibid 42.

67 The contexts in which Ren is used in the Analects do imply that Ren is primarily a quality of the agents.

${ }_{68}$ Mengzi (2001: 129). 
is designed to exclude the possibility of extended deliberation that might conceal the natural human reaction to the situation described in the thought experiment. Moreover, Mencius imposed several restrictions upon other possible relative factors that might motivate the observer's reaction.

Using this thought experiment, Mencius argued that the natural emotional reaction of a human being is alarm and compassion. Seeing this intuitive sympathetic reaction helps us to distil those human character traits that distinguish human beings from other animals. Mencius explicitly claimed, 'From this we can see that if one is without the heart of compassion, one is not a human'. ${ }^{69} \mathrm{He}$ then connected this emotional reaction with the narrow sense of Ren: 'The heart of compassion is the sprout of Ren. ${ }^{70}$

For Mencius, human nature is characterised by the natural course of human ethical development:

In general, having these four sprouts within oneself, if one knows to fill them all out, it will be like a fire starting up, a spring breaking through! If one can merely fill them out, they will be sufficient to care for all within the Four Seas. If one merely fails to fill them out, they will be insufficient to serve one's parents. ${ }^{71}$

Mencius's claim in this paragraph is that given the proper circumstances and what he calls the four sprouts, human virtues will naturally begin to grow or emerge and subsequently will achieve completeness or full development.

In the case of the development of virtues, according to Mencius, human moral agents themselves create the natural circumstances for development. This is why he claimed, 'To have these four sprouts but to say of oneself that one is unable to be virtuous is to steal from oneself..$^{72}$ The possession of the natural potential for virtue is sufficient to enable humans to acquire the virtues and hence to lead a virtuous life. ${ }^{73}$ This account can be characterised as a naturalistic developmental view of human nature. It is naturalistic, since good human nature is the normal expression of human nature, given the tendency of the development of particular species and the normal circumstances they live in. It is developmental, because it takes account of the process of the development instead of, say, stable functions of the complete or end state of the species.

This explanation of Mencius' conception of human nature lays the ground for a better understanding of the relationship between the broad sense and the narrow sense of Ren. Since the narrow sense of Ren is the ethical capacity of sympathy or caring for others, it defines genuine human nature. While the broad sense of Ren concerns the whole unity of human excellences or the complete humanity, it could be seen as the highest ethical achievement of human beings. Then, we

69 ibid.

70 ibid 130, with some modifications to the translation.

71 Ibid. The 'four sprouts' here are the emotions that function as the foundation of Mencius' four virtues. They are compassion, shame, deference, approval and disapproval.

72 ibid.

${ }^{73}$ Confucius has a similar remark. The Master said, 'Is Ren really so far away? If I merely desire Ren, I will find that Ren is already here.' Confucius (2001: 22), with some modifications to the translation. 
might claim that the broad sense of Ren is the final development of the narrow sense of Ren.

\section{A SKETCH OF A CONTEMPORARY GONFUGIAN VIRTUE JURISPRUDENCE}

The task in this section is the application of Confucian thought in the context of modern legal theory. This section deals with the basic structure of Confucian legal theory.

\section{A. Conceptual Clarification}

When we turn to the Confucian legal theory, the enterprise of reconstructing Confucian views runs into a significant obstacle: the three great Confucian figures of antiquity did not articulate well-developed or elaborate theoretical views about law in the modern sense. The reason for their failure to pay theoretical attention to law may be connected to the fact that law in ancient China did not play the central role that it does in contemporary western societies.

The relatively minor role of law in ancient China has at least two aspects. First, $\mathrm{Li}$ governed most of the social conduct in the Pre-Qin dynasty that modern societies regulate through formal positive law. Second, laws were enacted by rulers in particular states (of which there were many within the territory that constituted the larger social, cultural and linguistic community), and the application of law was limited by the geographical boundaries of those states. By way of contrast, $\mathrm{Li}$ had universal application (within the relevant social world): thus Li constituted 'the common norms of the ancient world' in ancient China. ${ }^{74}$

Given that $L i$ was the dominant normative system in ancient China, our inquiry may be illuminated by a conceptual comparison between $L i$ and law. But there is a potential confusion because of the linguistic dislocation of modern and ancient Chinese. The Chinese character $F a$ (法) is used as the parallel of law in translation between modern Chinese and English, but the ancient Chinese character $\mathrm{Fa}$ referred only to the rules governing punishment. ${ }^{75}$ So it is plausible to conclude that the main body of $\mathrm{Fa}$ in early Chinese history is limited as a subset of criminal law - essentially instructions to officials regarding criminal punishments. ${ }^{76}$

While $\mathrm{Fa}$ had a very limited scope, $\mathrm{Li}$ and modern positive law overlap to a significant degree. The first area of commonality occurs in those instances in which $\mathrm{Li}$ is codified and enacted by a political authority. $\mathrm{Li}$ (and not $\mathrm{Fa}$ ) governed the basic political institutions and governmental procedures and hence the behaviour

${ }^{74}$ Chang (1990: 9).

${ }^{75}$ According to Shang Shu (《尚書》), an ancient script, '(these) five kinds of punishment are called law'. Shang Shu: Lv Xin (《尚書·呂刑》).

${ }^{76}$ Hansen (undated). 
of officials. ${ }^{77}$ Most contemporary legal theorists believe that for a norm to count as positive law it must be enacted or practised by officials. So some parts of $L i$ share this crucial characteristic (governing official behaviour) with positive law. $\mathrm{Li}$ also included some norms or rules that would be classified as civil law in modern western legal systems. For example, marriage was regulated by $\mathrm{Li}$. Sometimes, $\mathrm{Li}$ functioned as an authoritative standard in dispute resolution. ${ }^{78}$ For these reasons, some historians claim that $L i$ was actually the ancient Chinese equivalent of the modern concept of law. ${ }^{79}$

In sum, we are dealing with three conceptions, corresponding to the phrase positive law and the ancient Chinese words $\mathrm{Fa}$ and $\mathrm{Li}$. Fa in ancient China referred only to the rules governing the imposition of punishment; these rules did not create legal obligations for legal subjects. $L i$ is a specific kind of social norm, including propriety, ritual, custom, etiquette and both customary and positive law: even when $L i$ was uncodified, it performed most of the social functions that law performs in contemporary western cultures. That is, $L i$ overlaps with the modern conception of positive law, but is not identical to it, encompassing some social norms that would not be classified as positive law on contemporary views of the nature of law.

\section{B. The End of Law}

Confucian philosophers did not take $F a$ as their central concern, but they addressed the ancient practices that roughly correspond to modern positive law. The traditional view of Confucius' attitude towards law is characterised in his injunction to 'eliminate litigation'. The Master said, 'In hearing litigations, I am as the others. The point is to eliminate litigation. ${ }^{80}$ Is 'eliminate litigation' a strong claim about all possible circumstances or is it a moderate claim limited to ideal circumstances? We believe that the moderate version provides both the best historical interpretation and the best contemporary reconstruction of the Confucian view.

Borrowing the distinction between first best and second best from economics illuminates our case for the moderate interpretation. Consider the first-best world of Confucian theory: in that world, the preconditions for an optimal harmonious Confucian society would be satisfied. These preconditions include the following: (1) each and every member of society would possess sufficient virtue; (2) the content of $L i$ would have been framed by the Sage Kings - who themselves would be fully virtuous, possessing Ren and $K i$; (3) $L i$ would be properly observed by the members of society, including those aspects of $L i$ that regulate or govern conduct

\footnotetext{
77 See Lifi: Wang Zhi (《禮記·王制》).

${ }^{78}$ See Lifi: $Q u \operatorname{Li}$ (《禮記·曲禮》).

79 See Mei (1975: 137).

${ }^{80}$ See de Montesquieu (1981: 3).
} 
(apologies, voluntary restitution, etc) after social conflict (to the extent it is unavoidable) has occurred. If these conditions (and perhaps others) were satisfied, then we would have the first-best state of society: in this state, the best policy for judicial activity is to eliminate litigation, or if that is not possible, to constrain litigation so that its occurrence is rare and exceptional. ${ }^{81}$

Suppose, however, that one of the preconditions for an optimal harmonious Confucian ideal society could not be fulfilled. For example, if some members of society do not possess the minimal amount of virtue required, then the public policy of 'eliminate litigation' may actually result in less harmony. Under these circumstances, some litigation should be encouraged to produce the best possible results given non-ideal conditions. Thus, we contend that the most reasonable interpretation of Confucius' remark, 'eliminate litigation', construes his injunction as a description of the first-best state.

Confucius' opinion about litigation leads us to our account of the ends of law. We begin with $L i$, because $L i$ played an essential role in the social and political life of ancient Chinese. We read in the Analects that '[i]n practicing Li, harmony is to be prized'. ${ }^{82}$ This conception of harmony has two aspects: harmony of society and harmony of the individual.

The first aspect of harmony is the social coordinative function of $L i$. This function of $L i$ is directed at the harmony of society; everyone has a proper position in the community regulated and guided by $L i$. We might call this aspect of harmony coordinative harmony. Given the similar coordinative functions of $L i$ in the ancient world of China on the one hand, and of law ${ }^{83}$ in modern society on the other, we conclude that coordinative harmony is an important end of law. In modern society, law creates a formal and relatively determinate guidance for social interaction as well as an ultimate standard of dispute resolution. In an ideal society, the dispute-resolution function of law is displaced by the law's action-guiding role.

The second aspect of the harmony-creating function of law is based on the premise that societies will function better if the rules of law are the object of voluntary compliance by individuals. Achieving voluntary compliance creates associated requirements for the inner dispositions possessed by the subjects of law. We might call this kind of harmony autonomous harmony. Autonomous harmony is related to the expressive function of $L i$. Individuals can express their emotions or exercise their virtues smoothly with the help of $L i$ and follow their own sentiments and desires without creating a breach of $\mathrm{Li}$. Since the natural tendency of moral development of human beings is defined by their affective and empathetic capacities, Confucian thinkers believe that given the external proper social circumstances and the natural development of affective capacity without disruption, humans can experience an inner harmony between their emotional state and the requirements of virtue.

\footnotetext{
${ }^{81}$ For a more complete account of the role of litigation, see Solum (2004: 181, 186-89).

${ }^{82}$ Confucius (1971: 143), with some modifications to the translation.

${ }^{83}$ Raz provides us with an insightful modern perspective of the coordination value of law. See Raz (1986: 57-62).
} 
Our notion of autonomous harmony depends on the constituent notion of autonomy. For our purposes, autonomy can be defined abstractly; Gerald Dworkin defines autonomy as 'a second-order capacity of persons to reflect critically upon their first-order preferences, desires, wishes, and so forth and the capacity to accept or attempt to change these in light of higher-order preferences and values' ${ }^{84}$ With this abstract concept of autonomy in mind, we can see how autonomous harmony works. Although the virtue of Ren is based on natural intuitive emotional reactions, possession of this virtue enables self-cultivating agents to, first, reflect on the natural de facto feelings, desires and impulses and, secondly, to reshape their behaviour without external direction. This satisfies the two elements required by the general concept of autonomy proposed by Gerald Dworkin: (1) the ability to perform, based on higher-order evaluation, critical reflection and (2) the freedom to lead a good life without direction from others.

Ren (or virtues) and $\mathrm{Li}$ (or social norms) are mutually supportive. In the context of traditional Chinese society, the relationship between internal dispositions and external norms is harmonised by the expressive function of $\mathrm{Li}$. Because $\mathrm{Li}$ embraced the highly uniform cultural values of ancient Chinese society, members of that society could successfully express their virtues autonomously. The autonomous harmony between conduct rules $L i$ and internal virtues Ren could be archived by the fully virtuous Junzi. This harmonious state is conveyed in Confucius' remark on his own experiences of self-cultivation: at 70, he could follow what his heart desired without disobeying the rules. ${ }^{85}$

But in modern societies, this might not be the case. On the one hand, there are differing and sometimes inconsistent values in modern societies characterised by value pluralism. On the other hand, law in modern society regulates behaviour rather than mental states, but virtue is constituted by inner dispositions. Law might have some expressive function, even if there might be an overlap in the content of law and the deeply held conventional norms in a given society, but the expressive function of law is quite limited given the fact of value pluralism.

Given these two factors, autonomous harmony cannot be fully achieved under contemporary conditions in the same way that Confucian thinkers believed it could in ancient China. For this reason, the development of contemporary Confucian virtue jurisprudence requires us to re-examine the relationship between law and virtue. When an agent performs actions in accord with external norms, she is fully autonomous if and only if she has critically reflected upon the norms and decided for herself to abide by the norms without any coercion, deception, or other forms of autonomy-nullifying interference. However, since humans have the potential to become fully virtuous, law can play a formative role that is consistent with autonomy during the process of moral development. During the time when an agent is developing the capacity to reflect on her own values, she must follow conduct rules which have not yet been thoroughly reflected upon and

${ }^{84}$ Dworkin (1988: 20).

85 See Confucius (2001: 5). 
endorsed autonomously. Absent such rules, the developing moral agent might injure others or invade their rights or act in ways that destroy her own capacity for critical self-reflection. The development of both virtue and autonomy is enabled by the developmental exercises that involve actions guided by the rules. Rules are necessary in the process of self-cultivation and habituation that enables individuals to develop the capacities and dispositions that constitute virtue and enable autonomy.

Autonomous harmony can be achieved by observing two moderate requirements for the content of law. The first requirement is that the range of legally permissible and legally required conduct should (a) permit a sufficient range of virtuous conduct and (b) not require vicious conduct. This requirement ensures that people can develop their natural capacities and maintain autonomy without violating the law. On the one hand, virtuous humans would then be enabled to lead virtuous lives according to their own conception of human flourishing without being subjected to compulsory interference. On the other hand, persons who do not possess the full measure of virtue are not forced to act in accord with values that they have not chosen autonomously.

The second requirement is that law should create conditions that can facilitate individuals in the development of virtue without offending the rights of others. In some situations, law may be able to create conditions that can gradually change people's moral preference. One of the well-known examples in the AngloAmerican tradition is provided by good Samaritan laws. The concrete content of good Samaritan laws varies from one jurisdiction to another, but the basic idea is that law exempts rescuers from certain kinds of legal liability and hence encourages rescue. To the extent that citizens learn the content and purposes of the law, laws of this kind can alter the moral preference of legal actors and help them in the development of virtues (and therefore, in Confucian terms, Ren).

In sum, the highest value of Confucian ethical, political theory is the harmony of society and individual. At the social dimension, we have coordinative harmony, which is related to the coordinative function of $\mathrm{Li}$. At the individual dimension, we have autonomous harmony, which is connected with the expressive function of $L i$. Because $\mathrm{Li}$ and law do not share the function of expression of dispositions and emotions, our claim is that law's ability to foster 'autonomous harmony' is limited in scope: whereas $L i$ can play a pervasive role in shaping values and virtues, the educative and developmental function of law is restricted. Of course, law can indirectly create the conditions for the development of autonomous harmony in other ways - by enabling, supporting and protecting the institutions that directly engage in moral education and development - primarily the family, schools and other institutions (such as religious institutions or voluntary social associations) ${ }^{86}$ 


\section{Names and Confucian Theories of Legislation and Adjudication}

Given coordinative harmony and autonomous harmony as ends of law, we need to provide an account of how the legal norms are internalised by legal actors. The Confucian doctrine of correcting names might give us an explanation of the mechanism of internalisation in terms of the relationship among social norms, law and names. Given the end of law as the coordination of social interactions and harmonious autonomy, we claim that there are important normative requirements regarding the usage of names in legislative and judicial proceedings.

We have already seen that names (thick ethical concepts) provide guidance for actions. Regicide and cruelty were provided as examples in our introduction of the doctrine of correcting names above. But regicide is thinner than cruel. The application of regicide requires a deep and complex evaluation of whether the person claiming to be a lord is virtuous and whether he fulfils the political obligations attached to his political role. ${ }^{87}$ But in the case of $\mathrm{cruel}$, we frequently do not need to engage in deep and complex evaluations prior to the application of the concept. Usually, we are able to see cruelty: we are able to perceive cruelty in the situation. In the case of regicide, more than perception is required. For this reason, we believe that regicide is thinner than cruel. Our view of the doctrine of correcting names explicitly adopts the idea that what we call the thickness of ethical concepts is scalar - although the scale may be coarse-grained rather than continuous.

We have already discussed the fact that in ancient Chinese society, $L i$ was the basic normative system 'involving rite, ceremony, manners or general deportment that bind human beings and the spirit together in networks of interacting roles' ${ }^{8}{ }^{8}$ Social interactions were coordinated by $L i$ and an individual's virtues were expressed with the help of $L i$. But it seems plausible that both $L i$ and names (thick ethical concepts) perform an action-guiding function. This common function leads naturally to the next question: what is the relationship between $\mathrm{Li}$ and names? There are two perspectives on this question.

From the first perspective, some thick ethical concepts in a given community are dependent on the normative system of that community. Consider regicide. The proper application of this term requires evaluation of the actions performed and character traits possessed by the political leader. In other words, the true ethical meaning of this name, as Mencius recovered it, makes reference to the normative requirement for the role of lord as specified by $L i$, the normative system of the community.

From the second perspective, however, it turns out that stable linguistic practice of thicker names is one of the necessary conditions for the action-guiding

87 These two kinds of evaluation are normally connected with each other since many political norms binding the ruler or subjects are so called v-rules. V-rules in ancient political morality can be expressed like this: Given a political virtue $\mathrm{X}$, the v-rule related to this virtue is 'perform actions in accordance with what an X agent would characteristically do in the circumstances'. A sophisticated discussion of V-rules can be found in Hursthouse (1999: 26-42).

${ }^{88}$ Schwartz (1985: 67). 
function of a normative system. Consider cruel. The proper application of $\mathrm{cruel}$ can (in normal circumstances, if not all circumstances) be accomplished without deliberation about or reliance on related social norms. But cruel plays a role in the system of norms. One can imagine a case in which the proper application of regicide would depend on whether someone was not properly described as a lord because of systematic acts of cruelty. Hence, the system of norms that provides the conditions for the correct application of the thinner name regicide includes thicker names such as cruelty.

These two perspectives on the relationship between $L i$ and names suggest that there might be a multi-layered structure concerning the thickness of the Confucian names. Thicker names like cruel or courageous are in the lower layers, layers that are tightly entangled with the non-ethical qualities of the world. Thinner names like regicide or thief, whose application may involve moral norms or other thicker names, are in the upper layers ${ }^{89}$ - where the entanglement of fact with value is mediated by the system of social norms. Due to their thinness, the layer of thinner names is tied more closely to $\mathrm{Li}$. Expressed from a different angle, the worldguidedness of thinner names is dependent on the normative system of particular communities.

This brings us to the relationship between thick ethical terms and legal terms. Williams discusses thick terms that are ethical, but for our discussion there is no reason to stick to this moral sense. We call the general notion thick evaluative concepts (or simply names) and the legal notion thick legal concepts (or legal names).

The paradigm cases of thick legal concepts, in Xunzi's discussion, are the names for punishments. In the contemporary legal context, the categories of different crimes provide good examples of legal names; these include robbery, theft, murder, rape, and so on. ${ }^{90}$ On the one hand, we have legal names like robbery or murder, which have a technical meaning in the legal context, but on the other hand, we use robbery or murder in the sense of general evaluative thick ethical concepts in our ordinary moral discourse. To avoid ambiguity, we might call the moral notion thick extralegal concepts and the legal notion thick legal concepts. ${ }^{91}$

Given that law is a normative system, the most fundamental function of law should be action guiding. What role do thick legal concepts play in law's actionguiding function? To answer this question, we need an account of the actionguidance function of law in general. We begin by observing that there are two

\footnotetext{
${ }^{89}$ Williams was criticised by Samuel Scheffler on the ground that he did not give us a well-defined notion of thick ethical concepts. Scheffler is worried that some concepts, such as 'justice' and 'equality', might not be confidently classified as either thick or thin concepts. See Scheffler (1987: 417).

In our interpretation of Confucian names, they can be located on the upper levels. Since they are at the very top level and hence lose most of the world-guidedness character, they might be viewed as thin ethical terms as well. Concepts of this sort cannot be classified as thicker or thinner according to their relation to norms.

${ }^{90}$ Antony Duff, in his discussion on the relationship between thick legal concepts and thick extralegal concepts, took the various kinds of crime as examples of thick concepts involved in the law. See Duff (2001: 191).

91 ibid.
} 
patterns for the action-guiding role of law: following Shapiro, we will call the first pattern epistemic guidance and the second pattern motivational guidance. ${ }^{92}$

The first pattern is epistemic guidance. To ensure that legal rules actually guide behaviour, individuals must know what is required by law. In the mode of epistemic guidance, legal subjects learn what is required by legal rule and perform actions required by law because of their knowledge of the rule. Their motives may or may not involve the aim of complying with the law; for example, knowledge of the law plus fear of punishment might produce compliance by agents who have no regard for the law itself.

The second pattern is motivational guidance, which can be seen as a subset of epistemic guidance. In the pattern of motivational guidance, legal subjects are successfully motivated by the legal content to actually perform law-abiding actions. For example, if an agent were moved by a desire to comply with the law, we would have a clear case of motivational guidance.

How do thick legal concepts contribute to the guidance function of law? First, consider the epistemic guidance role of rules and thick legal concepts. Suppose that a legal rule $\mathrm{R}$ employs a thick legal concept $\mathrm{T}$ to describe one of the essential premises for the application of that rule and/or the attribution of certain legal consequences. By incorporating a thick concept in that rule, legislators and judges could regulate a specific type of behaviour that might not be accomplished by employing merely descriptive concepts. Legal rules are designed to reflect practical concerns or interests. Thick concepts are perfectly suited to the task of formulating rules that capture these concerns and interests. The scope of the application of thick concepts is limited by the concerns or interests behind them and thus can precisely express the intention of legislators or judges. In this scenario, we might say that fraud is not just illegal and deceitful but it is illegal in the light of its deceitfulness. A citizen who grasps fraud would grasp the content of a legal rule using that term and understand which actions are within the scope of the rule.

Thick legal concepts also have motivational value for those who embrace them. For instance, if someone fully embraces the concept of cruelty and describes an action as cruel, she has a reason not to do that action. Suppose that a legal rule forbids parents from inflicting cruel punishment on their children and a particular parent fully embraces the concept of cruel, then that parent will be motivated to refrain from punishing her child in a cruel way.

Now consider the relationship between thick legal concepts and their raw form - thick extralegal concepts in ordinary moral or normative language. Some of the categories of crimes are the representatives of thick legal concepts, such as robbery, theft, murder and rape. On the one hand, we have thick legal concepts like robbery or murder, which have a technical legal meaning, but on the other, we use thick extralegal concepts like robbery or murder in our ordinary moral discourse. The fact that thick terms can have this dual role leads to the well-known

${ }^{92}$ See Shapiro (1998: 490). We will return to this point and have a more extended discussion in the next section. 
phenomenon of the same word having two different senses - a technical legal sense (the thick legal concept) in which the full content of the concept is specified by a system of legal norms and an ordinary sense (the thick extralegal concept) in which the content is based on the system of social norms. The two senses of the concept and the two systems of norms may interact with each other in complex ways - with the law both shaping and responding to the social norm system. Does the content of a thick extralegal concept in some way determine, shape, or constrain the content of a thick legal concept that shares the same name (eg 'murder' in ordinary discourse and 'murder' in the technical legal sense)?

One way to answer this question is to imagine an acoustic separation (as DanCohen has famously done in his account of conduct rules and decision rules ${ }^{93}$ between thick extralegal concepts understood by general citizens and thick legal concepts understood by legal experts. We can imagine that a society is divided into two separate discourse groups: in one discourse group we would have the general citizens and in the other group we would have legal experts, lawyers and legal officials. Suppose these two groups are acoustically separate from each other and they have the same legal text. And, let us further suppose that these two groups' understanding of the extensions of thick concepts does not have substantial overlap. If the law is to fulfil its crucial epistemic action-guiding function, the thick legal concepts and their extralegal versions have to share a similar normative shape.

Another argument in support of this conclusion is based on the motivational role of thick normative concepts. Thick concepts can reinforce the motivational force of law only when there is an overlap between the legal meaning of the concept and the ordinary meaning which is shaped by the values embedded in a specific cultural community conveyed through daily linguistic practice. If the legal technical meaning of thick ethical concepts becomes totally disconnected with their ordinary meaning, a linguistic barrier will be built between the legal elites and the lay citizens and the law will be in danger of losing its motivational power. From the perspective of ordinary citizens, the law will no longer make normative sense - the disconnected legal concept will seem arbitrary or unreasonable.

Confucian virtue jurisprudence holds that for law to guide conduct optimally, it must be capable of being internalised and thereby capable of generating motives for conformity by legal subjects. The correct use of names can help citizens to internalise legal norms and become naturally motivated to obey the law. Moreover, convergence between thick legal concepts and thick ethical concepts enables law to produce both coordinative harmony and autonomous harmony. Thus, the doctrine of correcting names explains how internalisation occurs and, at the same time, prescribes a normative requirement for the use of thick ethical concepts in legislation and by the judiciary. 


\section{The Nature of Law}

Some scholars have argued that Confucian theory of law, as it was developed in the classical literature without any further articulation, can be seen as a Chinese version of natural law, ${ }^{94}$ while others ascribe to it a Dworkinian coherentist reading. ${ }^{95}$ In this part of the essay, we address these arguments and take a step towards the development of a theory of the nature of law.

Informally, we might say that legal positivism claims that the question of whether a given rule is law can only be answered by consulting things like statute books, court decisions and patterns of behaviour by officials, whereas natural law theory asserts that the justice (or injustice) of a rule factors into the answer to that question. ${ }^{96}$ More technically, contemporary legal positivism asserts that it is necessarily the case that legal content is determined by social facts. Exclusive legal positivism claims that only social facts determine legal content, while inclusive legal positivism allows that moral facts may determine legal content, but only if social facts establish this role for moral facts. ${ }^{97}$ Natural law theory, on the other hand, claims that moral facts necessarily determine legal content.

Now consider our Confucian account of the nature of law. Our theory is both a positive as well as a normative theory of law. As a positive theory, it describes and explains how law functions in the society; as a normative theory of law, it sets up normative standards for the content of law and legal practice. Our positive theory is an explanatory functional conception of law, rather than a direct answer to the metaphysical or conceptual question 'What is law?' That is, in this essay, we adopt an agnostic stance on the debate between natural lawyers and legal positivists.

As we have seen earlier, Confucius believed that pre-Qin ancient Chinese law (Fa) could not serve as a normative system sufficient to provide guidance for actions; instead, he contended that only $\mathrm{Li}$ (social norms already internalised by community members) could fulfil this function. As we have discussed in last section, the action-guiding function of law is also the central theme in contemporary western analytic jurisprudence. A good place to start with is Hart's conceptual analysis of law. Hart took the guidance function as one of the basic functions that law serves. ${ }^{98}$

94 See Needham (1956: 544). See also Greer and Lim (1998: 80-89).

95 See Peerenboom (1990:12-39).

96 See Hart (1994). We choose Hart's theory of law as a point of comparison for two reasons. First, Hart's work is key to the evolution of modern positivist theory, representing the bridge between the positivism of Bentham and Austin and contemporary analytic positivism. Second, Hart's theory is the best-known version of contemporary positivism among legal theorists generally. Other important forms of legal positivism include those developed in the work of Coleman (2001); Kelsen (1945); Raz (1979); and Shapiro (2000: 127-70).

${ }^{97}$ Inclusive legal positivism accepts the view that legal contents and moral facts can be indirectly connected with each other.

${ }_{98}$ Hart writes (1994: 249): 'In fact I think it quite vain to seek any more specific purpose which law as such serves beyond providing guides to human conduct and standard of criticism of such conduct.' 
The primary aim of Hart's theory is a conceptual account of the nature of law, and hence an account of what counts as law and what does not. In this regard, this guidance function is a necessary but not sufficient condition for a normative system to qualify as a legal system. Hart added that this guidance function 'will not of course serve to distinguish laws from other rules or principles with same general aims' and 'the distinctive features of law are the provision it makes by secondary rules for the identification, change, and enforcement of its standards and the general claim it makes to priority over other standards. ${ }^{99}$ So, Hart's positivist account of the nature of law has two elements. The first is a second-order binding rule (a rule of recognition) that is applied by legal officials, including judges, administrative officials and legislators, as a standard of validity of law. The second element is acceptance by most individuals of the first-order rules (primary rules) validated by the rule of recognition. These two elements give rise to ontological criteria for the existence of a legal system in a given community. In a legal system, according to Hart, the binding second-order rule of recognition is a fundamental social norm, but valid first-order rules are not necessarily social norms because their validity is derived from the rule of recognition. What kind of guidance function, associated with the fundamental social norm and the rules that are derived from it, is involved here? Hart's answer to this question rested on his notion of internal point of view. An internal point of view is an evaluative perspective adopted by community members from which they see rules of law as their own reasons for actions and criticise others' behaviour when others disobey the law. ${ }^{100}$

By incorporating the idea of internal perspective, Hart presented two ontological standards for the existence of a rule: (1) a standard of the state of mind (internal point of view) and (2) a standard of behaviour (stable pattern of behaviour). According to this ontological standard, a rule exists in a community if and only if the relevant actors in that community take this rule as a reason for their action and their behaviour actually fits the pattern that is prescribed by that rule. By reading Hart in functionalist terms, Shapiro showed that there might be two patterns of rule guidance with regard to secondary social norms and primary conduct rules. ${ }^{101}$ Shapiro distinguished motivational guidance from epistemic guidance - along the lines we discussed above. On Shapiro's interpretation of Hart's account of legal guidance, lay citizens need not be motivationally guided by the content of law in order to obey the law, because epistemic guidance is sufficient.

Confucian virtue jurisprudence gives emphasis to the motivational process when legal subjects are guided by the law. Based on the distinction between epistemic and motivational guidance, we can articulate the general motivating process in legal domains like this:

\footnotetext{
99 ibid.

100 ibid 55-57.

101 See Shapiro (1998: 490).
} 
A legal subject $\mathrm{S}$ will perform rule-governed action $\mathrm{A}$ if and only if she learns that it would be required by rule $\mathrm{R}$ (epistemic judgement) and she is motivated by motivational factors Fs, which possibly (but not necessarily) include normative judgements and emotional reactions.

Thus, our theory takes a normative stance on the legal subjects' motives in law's guidance process. In a well-functioning rule-of-law society, according to Confucian thinkers, a sufficient number of citizens possess the virtue $Y i$. These virtuous citizens perform law-governed actions for the right reasons and with the right motivational attitudes; shame plays a crucial role in their motivational attitudes. Shame can be divided into two subcategories, conventional shame and ethical shame. A person with a sense of conventional shame only conforms to the rules because she is afraid of the social pressure generated by rule-breaking behaviour and not because she really thinks it is wrong to break that rule. Someone with a sense of ethical shame (or possessing the virtue of $k i$ ) abides by the rule because she thinks it is wrong to break the rule. For these people, the feeling of shame is raised from their own reflection on what they have done with regard to what kind of person they expect themselves to be.

Using Hart's terminology, the Confucian notion of an attitude towards rules that incorporates ethical shame as a focal motivation can be seen as a strong version of internal point of view. It is not clear, however, whether Hart would accept this Confucian account of the internal point of view. Hart explicitly claims that understanding his conception of internal point of view as internal feelings of compulsion or being bound and the externally observable physical behaviour is a misrepresentation of his account. ${ }^{102}$ Translating Hart's claim into Confucian language, it seems conventional shame cannot be a necessary part of the internal aspect of rules. Later on, Hart acknowledges that the internal point of view may display itself in self-criticism, ${ }^{103}$ but in legal contexts this self-criticism is not necessarily connected with a sense of shame because Hart classifies rules that give rise to shame when disobeyed as moral rules. ${ }^{104}$ So, Hart does not seem to endorse the strong Confucian claim that a well-functioning social order requires that subjects of the law must take this strong version of internal point of view towards legal rules. As we have discussed earlier, this strong version of internal point of view is at the centre of our Confucian theory of law.

This view of the internal aspect of law can be generalised as what we have called the Internalisation Thesis. In the original context, Confucius' internalisation thesis concerns $L i$, which is situated between morality and positive law (as those notions are understood in contemporary legal theory). Let's recall what Confucius has said:

The Master said, 'If the people be led by governmental regulations, and uniformity sought to be given them by punishments, they will try to avoid the punishment, but

\footnotetext{
102 Hart (1994: 57).

103 ibid.

104 ibid 86.
} 
have no sense of shame. If they be led by virtue, and uniformity sought to be given them by $L i$, they will have the sense of shame, and moreover will reform themselves. ${ }^{105}$

This leads to a possible objection to our account of the internalisation thesis: modern law (or positive law) does not necessarily share this expressive function with ancient $L i$. By definition, the content of $L i$ is internalised by social members. In the case of positive law in modern societies, however, the content of legal norms is frequently not internalised (or in some cases even known) by citizens.

This possible objection is illuminated by considering the Confucian attitude towards positive law. That attitude is based on the premise that a normative system, be it morality, social norms or positive law, functions well if and only if it is able to guide the behaviour of citizens. Confucian theory assigns the emotions of the subjects of the law a central role in determining the ability of norms to guide action. For Confucian virtue jurisprudence, in a well-functioning rule-of-law society most legal subjects must be motivated in the following way when they perform law-governed actions:

A legal subject $\mathrm{S}$ performs law governed action $\mathrm{A}$ if she learns that it would be required by legal rule $\mathrm{R}$ (epistemic judgement) and she is motivated by motivational factors Fs, which includes normative judgements and emotional reactions.

Since we have already shown the value of thick legal concepts in legal contexts, the normative judgement here could either be an intuitive, thick judgement (with the help of thick concepts) or an reflective, overall judgement (about the all-thingsconsidered rightness or wrongness of an action). The presumption under this formulation of law-guided action is that the epistemic apprehension of a legal requirement cannot guarantee the motivational state. For Confucius, in a wellfunctioning society, legal actors' motivational states and their knowledge of law should be in a harmonious relationship. If the content of a legal rule is fully understood by a legal actor with a proper motivational state in place, then we would say that this rule is internalised by that legal actor.

Since we are dealing with a Confucian account of the nature of law, a question naturally arises as to what kind of law can be internalised by virtuous legal subjects. Before we answer this question directly, consider a dialogue in the Analects:

The Duke of She told Confucius. 'There is an upright man among my people. His father stole a sheep, and he testified against him.'

Confucius replied, 'Among my people, those we consider "upright" are different from this: fathers cover up for their sons, and sons cover up for their fathers. This is what it means to be "upright.", 106

At first glance, the issue concerned in this dialogue has the character of a moral dilemma. Testifying against a criminal is a civic duty required by political morality, but the crime to be reported is performed by one's father. The virtue of filial

${ }^{105}$ Confucius (1971: 146), with some modifications to the translation.

106 Confucius (2001: 36), with some modifications to the translation. 
piety and the rules in $L i$ require that one should love one's father and thus should cover up this crime to protect him from serious punishment. Confucius' resolution of the dilemma seems to suggest that in this specific circumstance, the virtuous agent should not report the crime. Given Confucius' particularism, his resolution should not be interpreted as a universal claim about all cases that share the basic structure described in the dialogue. ${ }^{107}$

The reason for Confucius' resolution of the dilemma is not clear in the dialogue. ${ }^{108}$ Our interpretation is that the strong emotions of love and affection that a good son has towards his father override the civic duty to report a trivial case of theft. One of the basic presumptions of Confucian virtue ethics lies in its rolebased character, so moral requirements differ according to the roles an agent possesses in her ethical relations. Because the son is in this special relation to his father, he should care more deeply for his father than should ordinary community members.

What then is the implication of this dialogue? Suppose that in the state where this dialogue happened, there was a general legal rule that requires citizens to report every crime, including crimes committed by one's close family members. From a Confucian point of view, this rule should neither have been enacted nor be enforced, because the rule goes against the natural sentiments of legal subjects and thus could not be fully internalised by virtuous actors.

This claim can be seen as a normative account of the content of law. As characterised from a Confucian perspective, we can make a normative claim about the content of law based on the internalisation thesis:

The content of law should be such that the law can be internalised by legal actors to the extent required for law to perform its essential function of action guidance.

Two further points clarify this claim. First, this claim about the content of law should be restricted to those legal rules that have morally significant content. Rules concerning purely coordination or the efficiency of social interactions have nothing to do with this internalisation thesis; and technical rules which are not directly related to the citizen's ordinary life are excluded as well. In this regard, there is no requirement of the capability of internalisation for the content of regulations requiring all traffic to keep either to the left or the right side of the road or for legal rules governing the use of the radio spectrum.

Second, intuitive emotional reactions are essential elements of social norms $(L i)$, but social norms also reinforce or weaken emotional reactions. In a society like that of ancient China, which highly values family relations, one's intuitive emotional reaction of filial piety might be stronger than that in modern societies. If

107 eg consequence matters here. Let's imagine that his father has conducted a crime of manslaughter, then what would Confucius say about this? We do not know, but Confucius would probably not suggest that the son cover up the father's crime in this case.

108 Some commentators provide us with a nepotistic, as well as consequentialist, reading. They suggest that Confucius saw filial piety as the foundation of the development of any other virtues, or, family relation as the most fundamental social relation for human beings, without which the society will collapse. See Chen (1990: 925). 
this is the case, then social norms and law do share some content with regard to the very deep moral intuitions of human beings, but that content might be slightly different depending on the fundamental values embedded in different communities' social norms. Take the mutual concealment of father and son as an example. Similar principles of the concealment between close family members are found in several legal cultures, be it modern or ancient, east or west. But the specific content of this principle in a legal culture varies depending on the fundamental values embedded in the social norms in that culture.

This brings us back to the relationship of Confucian virtue jurisprudence to legal positivism and natural law theory. Because our theory offers a normative and functionalist account of law, its relationship to contemporary debates over the nature of law is oblique. Our theory does not take a direct stand on the question of whether social facts (or moral facts) determine legal content. So it seems, on the surface at least, that Confucian virtue jurisprudence might be consistent with either natural law or legal positivism.

At this point, a legal positivist might offer the following objection. Our theory seems to require a substantial overlap between thick legal concepts and thick moral concepts. So the legal concept of cruelty would have to have substantially the same content as the thick moral concepts. This might seem to lead to the conclusion that legal content is determined by moral facts, but legal positivists deny that this can be the case - while natural lawyers affirm that it must be.

But this objection would be based on a misunderstanding of our theory. We do not claim that thick legal concepts must substantially overlap with thick ethical concepts as a matter of legal ontology. That is, we are not claiming that a thick legal concept like cruelty would not be positive law if it were detached from the thick ethical concept whose name it shares. Our claim is simply that detachment would prevent the legal concept from guiding behaviour in the way that it should.

This point about the limited nature of our claim becomes clear in the extreme case of detachment - acoustic separation. Suppose that the system of adjudication were to employ a legal concept of cruelty that was radically different than the ordinary moral concept - and that ordinary citizens were completely unaware of the technical legal notion of cruelty. In those circumstances, the legal concept could still be called law, because it would provide the standard for authoritative legal resolution of disputes, but the legal concept could not properly fulfil the action-guiding function of law, since citizens would be unaware (or only partially aware) of the technical legal concept.

\section{CONCLUSION}

We have offered a sketch of Confucian virtue jurisprudence, a distinctive position in the general theory of law that has its ancient roots in classical Confucian thought in China. We interpreted Confucian ethical and social thought as a version of virtue ethics. That interpretation served as the basis for developing a 
contemporary legal theory. The core of our theory is our account of law's proper function, which we can summarise as the creation of a social order on the basis of coordinative harmony and autonomous harmony. That is, we believe that the aim of law is to provide a social order that rests on norms that can be internalised by autonomous agents who possess certain virtues. In other words, our view of law reconciles individual freedom and social order via the fundamental Confucian notion of harmony.

\section{REFERENCES}

Ames, RT and Rosemont, H (1988) The Analects of Confucius: A Philosophical Translation (New York, Ballantine Books).

Blackburn, S (1992) 'Through Thick and Thin' 66 Proceedings of the Aristotelian Society, Supplementary Volumes 285.

Chang, KC (1983) Art, Myth, and Ritual: the Path to Political Authority in Ancient China (Cambridge, MA, Harvard University Press).

Chang, W (1990) Traditional Chinese Furisprudence: Legal Thought of Pre-Qin Thinkers (unpublished manuscript).

Chen, S (1990) Lun Ru Fi Shi (《論語集釋》) (Beijing, Commercial Press).

Chow, KW (1994) The Rise of Confucian Ritualism in Late Imperial China: Ethics, Classics, and Lineage Discourse (Stanford, Stanford University Press).

Clark, SJ (2012) 'Neoclassical Public Virtues: Towards an Aretaic Theory of Law-Making (and Law Teaching)' chapter 5 of this volume.

Coleman, J (2001) The Practice of Principle (New York, Oxford University Press).

Confucius (2001) 'Analects' in EG Slingerland (tr), PJ Ivanhoe BW and van Norden (eds), Readings in Classical Chinese Philosophy (New York, Seven Bridges).

- (1979) 'Analects' in DC Lau (tr), The Analects (New York, Penguin Books).

(1971) 'Analects' in J Legge (tr), Confucian Analects, The Great Learning, and The Doctrine of the Mean (New York, Dover Publications).

Cua, AS (1971) 'Reflections on the Structure of Confucian Ethics' 21 Philosophy East and West 125 .

- (2007) 'Virtues of Junzi' 34 Journal of Chinese Philosophy 125.

Dan-Cohen, M (1984) 'Decision Rules and Conduct Rules: On Acoustic Separation in Criminal Law' 97 Harvard Law Review 625.

Dancy, J (1996) 'In Defence of Thick Concepts' 20 Midwest Studies in Philosophy 263.

de Montesquieu, C, Fu, Y (tr) (1981) The Spirit of Lawes (Beijing, Commercial Press).

Duff, RA (2001) Punishment, Communication, and Community (New York, Oxford University Press).

Dworkin, G (1988) The Theory and Practice of Autonomy (New York, Cambridge University Press).

Eno, R (1990) The Confucian Creation of Heaven: Philosophy and the Defense of Ritual Mastery (Albany, State University of New York Press).

Farrelly, C and Solum, LB (eds) (2007) Virtue Furisprudence (Basingstoke, Palgrave Macmillan). Feldman, H (1994) 'Objectivity in Legal Judgment' 92 Michigan Law Review1 187.

Fung, YL (1952) A History of Chinese Philosophy: The Period of the Philosophers, Volume I (Princeton, Princeton University Press). 
Gier, N (2001) 'The Dancing Ru: A Confucian Aesthetics of Virtue' 51 Philosophy East and West 280.

Goldie, P (2008) 'Thick Concepts and Emotion' in D Callcut (ed), Reading Bernard Williams (London, Routledge).

Greer, S and Lim, TP (1998) 'Confucianism: Natural Law Chinese Style?’ 11 Ratio Furis 80.

Hansen, C Rule of Law in Ancient China: Chinese Substance or Western Function? (Available at: www.hku.hk/philodep/ch/Substance-Function.htm, visited 4 May 2009).

Hart, HLA (1994) The Concept of Law (Oxford, Clarendon Press).

Hursthouse, R (1999) On Virtue Ethics (Oxford, Oxford University Press).

Kelsen, H (I945) General Theory of Law and State (Cambridge, MA, Harvard University Press).

Mencius (2001) 'Mengzi' in BW van Norden (tr), PJ Ivanhoe and BW van Norden (eds), Readings in Classical Chinese Philosophy (New York, Seven Bridges).

Mei, Z (1975) 'Li and Fa' in D Xu (ed), Essays on Chinese Legal History (《中國法制史論 集》) (Taipei, Zhiwen Press).

Needham, J (1956) Science and Civilization in China vol 2 (Cambridge, Cambridge University Press).

Nuyen, A (2009) 'Moral Obligation and Moral Motivation in Confucian Role-Based Ethics' 8 Dao 1.

Payne, A (2005) 'A New Account of Thick Concepts' 39 Journal of Value Inquiry 89.

Peerenboom, R (1990) 'Confucian Jurisprudence: Beyond Natural Law' 18 Asian Culture Quarterly 12.

Raz, J (1979) The Authority of Law: Essays on Law and Morality (Oxford, Clarendon Press).

- (1986) The Morality of Freedom (Oxford, Oxford University Press).

Schauer, F (2010) 'Necessity, Importance, and the Nature of Law' Virginia Public Law and Legal Theory Research Paper No 2010-19 (Available at www.ssrn.com/abstract=1594930).

Scheffler, S (1987) 'Morality Through Thick and Thin: A Critical Notice of Ethics and the Limits of Philosophy' 96 Philosophical Review 411.

Schwartz, BI (1985) The World of Thought in Ancient China (Cambridge, MA, Harvard University Press).

Shapiro, SJ (2000) 'Law, Morality and the Guidance of Conduct' 6 Legal Theory 127.

- (1998) 'On Hart's Way Out' 4 Legal Theory 469.

Shun, WL (1997) Mencius and Early Chinese Thought (Stanford, Stanford University Press).

Slingerland, E (2001) 'Virtue Ethics, the Analects, and the Problem of Commensurability' 29 Journal of Religious Ethics 97.

Slote, MA (1992) From Morality to Virtue (New York, Oxford University Press).

Solum, LB (2004) 'Procedural Justice' 78 Southern California Law Review 181. - (2006) 'Natural Justice' 51 American Fournal of Jurisprudence 65.

van Norden, B (2007) Virtue Ethics and Consequentialism in Early Chinese Philosophy (New York, Cambridge University Press).

Wang, L (2010) Living by Thick Legal Concepts: A Confucian Account of How Law Guides People's Actions (Unpublished manuscript: Presented at University of Illinois).

Williams, B (2006) Ethics and the Limits of Philosophy (London, Routledge).

Wong, WY (2001) 'Confucian Ethics and Virtue Ethics' 28 The Journal of Chinese Philosophy 285.

Xun Zi (2001) 'Xunzi' in EL Hutton (tr), PJ Ivanhoe and BW van Norden (eds), Readings in Classical Chinese Philosophy (New York, Seven Bridges).

Yu, J (1998) 'Virtue: Confucius and Aristotle' 48 Philosophy East and West 323. 
